\title{
Prisioneiro, militante e escritor: um novo olhar sobre as Memórias do cárcere e o seu autor
}

Elisa Scaraggi

\author{
Alves, Fabio Cesar. Armas de papel: Graciliano Ramos, as Memórias do cárcere e o \\ Partido Comunista Brasileiro. São Paulo: Editora 34, 2016, 336 p.
}

Dentro do corpus literário de Graciliano Ramos, as Memórias do cárcere ocupam um lugar de exceção. Embora não sejam a única incursão do autor na autobiografia, as Memórias são o primeiro livro que ousa aventurar-se abertamente no terreno da história: mediante um relato em primeira pessoa, o autor lança um olhar lúcido sobre alguns dos aspectos mais sombrios do Brasil durante a Era Vargas.

Por essas caraterísticas, e pelo indiscutível valor literário, as Memórias do cárcere têm recebido a atenção e a dedicação de muitos críticos. Porém, como observa Fabio Cesar Alves na apresentação do seu Armas de papel, recentemente publicado pela Editora 34, "boa parte das análises sobre o livro [tem] preferido deter-se nas questões relativas ao gênero híbrido ou à própria linguagem, quando não às particularidades do testemunho" (p. 17). Ao contrário, o que Alves se propõe a fazer é desvendar a complexa rede de referências históricas e factuais sobre a qual se estrutura a narrativa das Memórias, recorrendo, quando necessário, a material de arquivo e a outros textos do autor. Para o crítico, traçar o quadro histórico do contexto da prisão de Graciliano, assim como do contexto no qual ele escreve as Memórias, é essencial para reconhecer as vozes distintas que se misturam no texto. Isso representa uma novidade nos estudos sobre a obra, dado que, embora outros tenham indicado a multiplicidade de vozes que nela aparecem - e penso aqui em um célebre artigo de Boris Schnaiderman ${ }^{1}-$, poucos fizeram desse ponto o eixo da própria análise.

A tese principal de Armas de papel, livro que nasce da pesquisa de doutorado de Alves, é que, a partir da reconstrução da experiência nas prisões varguistas, Graciliano

1 SChNAIDERMAn, Boris. 1995. “Duas vozes diferentes em Memórias do cárcere?”. Estudos Avançados, vol. 9, n. 23, pp. 332-7. 
pretendia contribuir à discussão sobre temas relevantes para o próprio presente. Por isso, o crítico afirma que a obra apontaria "para impasses históricos irresolvidos e para a permanência de conflitos da subjetividade e da militância de esquerda” (p. 27). Essa perspectiva permite que a análise não fique presa à questão da denúncia do trauma vivido pelo ex-prisioneiro, algo que tem dominado os estudos da memória e a literatura do testemunho.

A ênfase dada ao contexto histórico e às referências factuais, porém, não implica que a análise se baseie apenas em elementos extratextuais. De fato, um dos aspectos mais interessantes de Armas de papel é o foco no narrador, pois para Alves "todo o movimento da composição das Memórias [...] consiste no relato factual somado à crispação do narrador" (p. 82). Por exemplo, logo na abertura, esmiúça-se ponto a ponto o discurso do narrador no primeiro capítulo das Memórias, no qual Graciliano atesta a vontade de se esquivar do modelo da reportagem de denúncia para se fincar na mais pura literatura, reclamando o direito de não seguir métodos e de preencher os vazios da memória como melhor entender. ${ }^{2}$ Segundo Alves, essa declaração de intenções demonstra a força do narrador e a sua determinação para escrever sobre a prisão, respondendo a um imperativo ético que o leva a superar hesitações e perplexidades.

Armas de papel fornece também uma possível explicação sobre o porquê de a obra de Graciliano ter sido publicada de maneira póstuma, sendo que, segundo um documento manuscrito, ${ }^{3}$ ela já tinha sido concluída em 1951. É certo que o próprio autor admitia essa probabilidade, o que podia até ser vantajoso, pois assim se evitariam eventuais dissabores com quem se viu retratado no livro. No entanto, além da reação

2 “[...] não me obrigo a reduzir um panorama, sujeitá-lo a dimensões regulares, atender ao paginador e ao horário do passageiro do bonde. Posso andar para a direita e para a esquerda como um vagabundo, deter-me em longas paradas, saltar passagens desprovidas de interesse, passear, correr, voltar a lugares conhecidos. Omitirei acontecimentos essenciais ou mencioná-los-ei de relance, como se os enxergasse pelos vidros pequenos de um binóculo; ampliarei insignificâncias, repeti-las-ei até cansar, se isto me parecer conveniente" (RAmos, Graciliano. Memórias do cárcere. Lisboa: Editora Portugália, [1953] 1970, p. 9). 3 Trata-se de uma descrição das datas em que Graciliano começou e terminou de escrever todos os capítulos das Memórias. Pelo que consta, o último capítulo da quarta parte, “Casa de correção", foi terminado no dia $1^{\circ}$ de abril de 1951. Segundo relata Ricardo Ramos na "Explicação final” que segue às Memórias, quando o pai morreu ainda lhe faltava escrever um capítulo sobre as primeiras sensações da liberdade. Contudo, esse capítulo não consta do manuscrito (cf. Arquivo Graciliano Ramos, IEB-UsP. Série: Manuscritos, GR - M. 06. 144). 
de seus companheiros de reclusão, as criaturas vivas que ele sentia receio de jogar no papel, Graciliano temia a reação dos dirigentes comunistas. Vale a pena lembrar que Graciliano se filiou ao РСв só em 1945, oito anos depois de ter saído da cadeia. Daí em diante, sempre se proclamou orgulhoso de ser comunista, vindo a apoiar oficialmente as decisões do partido, ainda que sem renunciar ao seu espírito crítico, conforme Armas de papel mostra. Como reagiriam os dirigentes do РСв diante de um narrador que expunha publicamente as suas fraquezas e contradições, que não fazia questão de colocar-se como herói, que tinha amigos entre ladrões e militares e condenava alguns comunistas de carteirinha? Como reagiriam diante do desvelamento de "tabus e temas explosivos" (p. 45)?4

Nos cinco capítulos que compõem o livro de Alves, o crítico se debruça sobre algumas dessas questões espinhosas, entre as quais: o desenvolvimento do capitalismo no Brasil; os preconceitos de gêneros e de classe no país e dentro do PCB; a crítica à militância cega e ao Levante de 1935; as relações interpessoais na cadeia e a análise daquela que, para usar uma expressão de Primo Levi, poderíamos chamar de "zona cinzenta", espaço onde os carrascos podem ser amáveis e os companheiros terríveis. São esses os pontos críticos do diálogo que, nos anos 1940-50, Graciliano tenta estabelecer com os seus contemporâneos, com os militantes do РСB e, de forma geral, com a esquerda brasileira.

O crítico revela também como o narrador das Memórias questiona o funcionamento farsesco da justiça no estado burguês moderno para chegar à conclusão de "que o estado normal é a exceção que, vez ou outra, se declara abertamente" (p. 91). A anomia da situação vivida por Graciliano - e vale a pena lembrar que o escritor ficou preso durante onze meses sem acusação nem julgamento oficial - o leva a perceber que a vida na cadeia se baseia numa série de leis pessoalizadas. Alves tem o mérito de não deixar a análise encurralada no espaço da prisão: nessa caraterística da sociabilidade, por exemplo, ele enxerga um "traço formativo da identidade nacional" (p. 103), remontando ao conceito de cordialidade formulado por Sérgio Buarque de Holanda. Gilberto Freyre, outro grande crítico da década de 1930, é chamado em causa por Alves para questionar a ordem patriarcal que parece dominar as relações de Graciliano com a própria mulher, com as mulheres em geral e com os homossexuais conhecidos na cadeia.

\footnotetext{
4 Podemos ter uma ideia de como reagiriam os dirigentes comunistas graças ao relato de Ricardo Ramos, citado por Alves, que "salienta as acusações feitas de maneira informal pelo PC de que o livro seria "o elogio da polícia e da pederastia” (p. 101).
} 
Nesse caso e em outros, o livro põe o leitor de cara com algumas das autocríticas mais profundas do escritor, expressas segundo uma fórmula cujo funcionamento é identificado sob o nome de crispação. Tal arranjo formal, que "implica uma oscilação da prosa entre o relato dos fatos e as questões pessoais e políticas que cercam o narrador" (p. 294), é o verdadeiro traço distintivo das Memórias e, para Alves, nele se espelha a "condição de imobilidade prática dos intelectuais de esquerda do período" (p. 302).

Todavia, a imobilidade prática não impede o narrador das Memórias de intervir no debate público e de mostrar como a modernidade brasileira, tão celebrada e invocada por Getúlio Vargas e pelos governantes que o sucederam, se baseia em formas de sociabilidade arcaicas: a ordem patriarcal, a pessoalização das leis, os preconceitos raciais, a exploração dos sujeitos mais fracos.

Embora tenham passado mais de oitenta anos da prisão de Graciliano e mais de sessenta da publicação das Memórias do cárcere, o Brasil ainda é assolado pela permanência desses arcaísmos. As armas que Graciliano Ramos tinha para lutar eram "fracas e de papel", entretanto elas ainda podem ser úteis para quem queira entender o presente à luz do passado. E com certeza, nessa tarefa, o livro de Fabio Cesar Alves é um ótimo guia.

Elisa Scaraggi é Mestre em Literaturas Modernas, Comparadas e Pós-Coloniais pela Universidade de Bolonha 